This is an electronic reprint of the original article. This reprint may differ from the original in pagination and typographic detail.

Author(s): Rautamies, Erja; Poikonen, Pirjo-Liisa; Vähäsantanen, Katja; Laakso, Marja-Leena

Title: $\quad$ Teacher-child relationships narrated by parents of children with difficulties in selfregulation

Year: $\quad 2016$

Version:

Please cite the original version:

Rautamies, E., Poikonen, P.-L., Vähäsantanen, K., \& Laakso, M.-L. (2016).

Teacher-child relationships narrated by parents of children with difficulties in selfregulation. Early Child Development and Care, 186(11), 1846-1858.

https://doi.org/10.1080/03004430.2015.1135429

All material supplied via JYX is protected by copyright and other intellectual property rights, and duplication or sale of all or part of any of the repository collections is not permitted, except that material may be duplicated by you for your research use or educational purposes in electronic or print form. You must obtain permission for any other use. Electronic or print copies may not be offered, whether for sale or otherwise to anyone who is not an authorised user. 
Early Child Development and Care

Received: 4 Dec 2015, Accepted: 20 Dec 2015, Published online: 02 Feb 2016

\section{Teacher-child relationships narrated by parents of children with difficulties in self-regulation}

Erja Rautamies, Pirjo-Liisa Poikonen, Katja Vähäsantanen, Marja-Leena Laakso

Faculty of Education, University of Jyväskylä, Finland

This study addresses the relationships between teachers and children (4 - 6 years old) with difficulties in self-regulation from the parent's point of view. Narratives were constructed in 21 interviews with parents of children who have difficulties in self-regulation. The study focused on two questions: i) What kinds of teacher-child relationships can be identified in the parents' narratives? and ii) How is the child positioned in this relational context? The teacher-child relationships found were labelled neutral, problematic and caring. Within these categories, the child was positioned in nine ways ranging from the child as troublesome to the child as unique. The study offers tools for analyzing the teacher-child relationship. It helps to understand this relationship from the parental point of view, thereby contributing to the objective of supporting the development and wellbeing of children in the early childhood education context in cooperation with their parents.

Key words: teacher-child relationship, self-regulation, early childhood education and care, narrative research, position, parent 


\section{Introduction}

The teacher-child relationship has been identified as a key element in a child's development and well-being, and in the giving of high quality care and education in early childhood education settings (Howes \& James, 2002). It has been focus of several studies in daycare centers and in schools, and has typically been measured by teacher-reports based on questionnaires and interviews and also by observational data (Pianta, 1999; Sabol \& Pianta 2012). However, it has been less examined via qualitative methods from the parent's point of view, especially where it concerns the relationship between teachers and children at risk in forming positive teacher-child relationship (see Sabol \& Pianta, 2012). This study examines the teacher - child relationship in the Finnish early childhood education and care context (ECEC) from the parent's point of view by utilizing the narratives of parents who have a child with difficulties in self-regulation. Such problems are typically manifested as a child's difficulties in behavioral and emotional control, i.e., as challenging behavior on the part of the child (Bronson, 2000). These difficulties in self-regulation affect both the peer and teacher-child relationship (Lundan, 2009; Suoninen \& Lundan, 2005) and strongly influence the child's socio-emotional well-being (Savina, 2014). Such a child may thus be negatively positioned as a 'difficult child' in a daycare center in the speech of the teachers (Pihlaja, 2008). Studying the teacher-child relationship from the parent's point of view with a focus on the positioning of the children with difficulties in self-regulation behaving child in this relationship could contribute new understanding on the elements involved in building good teacher-child relationship in the ECEC context.

The critical factors supporting children with difficulties in self-regulation in the ECEC context are a good teacher-child relationship and a sensitive and confidential parent-teacher relationship (Bromer, 2011; Merritt et al., 2012). In Finland, parents are important partners in the domain of institutional early childhood education. According to the National Curriculum Guidelines (2005), the principle objective of early childhood education and care in Finland is to promote the child's overall wellbeing. This goal can be fostered, in particular, through good quality relationships with children and families. Parents have an important role in ECEC in supporting their child's growth, development and learning and in the process of early identification of children with a need for special support. According to the current Finnish care guidelines, special support should be given as soon as possible to both child and parents when a child has difficulties with self-regulation (Riikola et al., 2013). Childs' behavior may increase parental stress and parents’ negative educational practices, and for parents in this situation, daycare educators are key sources of support. Such support entails 
more intensive co-operation between parents and ECEC educators, which in turn entails confidential relationships between the two parties. A feeling of trust (Mishra, 1996; TschannenMoran, 2001) is the prerequisite for the formation of confidential teacher-parent relationships (Kikas et al., 2011). For parents, trust is strongly influenced by their interpretation of the teacherchild relationship. For this reason, we considered it important to examine parent's views of the teacher-child relationship.

\section{Teacher-child relationship}

The teacher-child relationship has been approached from several theoretical frameworks. At first, research was strongly influenced by attachment theory (Gregoriadis \& Grammatikopoulos, 2014; Sabol \& Pianta, 2012). The quality of a child's attachment and the kinds of working models (Bretherton, 1985, 1991) have an important impact on the child's formation of relationships, behavior in social situations, and sense of self later in life (Bergin \& Bergin, 2009; Howes \& James, 2002). The studies based on attachment theory have helped in identifying the key elements of a high quality teacher-child relationship and understanding of the emotional aspects of that relationship (Bergin \& Bergin, 2009; Sabol \& Pianta, 2012). The teacher-child relationship has been characterized, for example, as positive and secure, functional, negative and insecure, and conflictual and dependent (Gregoriadis \& Grammatikopoulos, 2014, Mantzicopoulos, 2005; Pianta, 1994, 1999). Closeness, open communication, conflict and dependence have been identified as important dimensions of the teacher-child relationship (Pianta 1994; Sabol \& Pianta, 2012). High levels of closeness and low levels of conflict have been proposed as the signs of a high quality teacher-child relationship (O’Connor, 2010). The teacher’s sensitivity (Pianta \& Sabol, 2012) and physical and emotional availability (Bergin \& Bergin, 2009), which mean openness to a child’s request for help and awareness of a child's needs are also important in forming a good teacher-child relationship. Secure attachment to teachers is linked to school success and child well-being (Bergin \& Bergin, 2009). Looking at the teacher-child relationship through the lenses of the attachment theory is useful, especially when studying the perceptions of parents. However, there are other fruitful concepts that can be employed. For example, interactional and sociocultural thinking emphasize the influence of context on how the teacher-child relationship is formed and evaluated (Pianta, 1999). The studies based on the ecologically oriented systems theory and on the developmental systems theory has enriched understanding of the teacher-child relationship by placing it in a broader context (Sabol \& Pianta, 2012). The most recent studies have also contributed to understanding of teacher-child relationships in schools and ECEC settings in different cultural contexts (Ebbeck \& Yim, 2009; Fumoto, 2011; Gregoriadis \& Grammatikopoulos, 2014; Joshi, 2009; Page \& Elfer, 
2013; Zhang \& Nurmi, 2012).

\section{Teacher-child relationship when a child has difficulties in self-regulation}

This study focused on the relationship between the teacher and a child with difficulties in selfregulation. Such difficulties typically manifest as disobedience, hyperactive and impulsive behavior and conflicts with other children (i.e. externalization) (Bronson, 2000). Other possible manifestations are distress, shyness, inhibition and withdrawal behavior (i.e. internalization) (Bronson, 2000). These different manifestations are connected to the child's temperament (Rothbart \& Derryberry, 2002). Self-regulation is linked to the child's goal-oriented behavior and ability to follow rules (Barkley, 2004). According to Vygotsky (1962, 1978), self-regulation develops from interpersonal control to intrapersonal control (see Savina, 2014). In this process, the internalization of speech (Barkley, 2004) is important, as also are the roles of parents and teachers. The quality of the teacher-child relationship may either increase or decrease children's internalizing and externalizing problems (O’Connor, Dearing \& Collins, 2011; Zhang \& Nurmi, 2012). Low teacherchild conflict and high teacher-child closeness are associated with a decrease in a child's externalizing behavior (Silver, Measelle, Armstrong \& Essex, 2005) and an increase in a child's social competence (Zhang \& Nurmi, 2012). Thus the teacher-child relationship is seen as a protective factor for children who are at risk for externalizing behavior (Sabol \& Pianta, 2012) and who have adjustment problems (Hamre \& Pianta, 2005).

Children with externalizing problems, such as aggression and hyperactivity, are more likely to have conflicts with teachers, a situation more typically encountered with boys (Buyse et al., 2008; Silver et al., 2005), while there is also a risk for the development of a maladaptive interaction cycle between a teacher and a child (Doumen et al., 2008; Sabol \& Pianta, 2012; Zhang \& Nurmi, 2012). In the longitudinal study by Doumen et al. (2008), children's aggressive behavior predicted teacherchild conflict at the beginning of the kindergarten year; this in turn predicted children's aggressive behavior later. In the ECEC context, a positive relationship between teacher and child is strongly connected to the children's social and emotional well-being (Fattore, Mason \& Watson, 2006). The quality of the teacher-child relationship is especially important for children's self-regulatory development (Pianta \& Stuhlman, 2004; Merritt et al., 2012). Teacher’s emotional support (sensitivity and emotional involvement, warmth and respectful interaction) in relational and classroom context can, in particular, be seen as a protective factor for children's internalizing and externalizing behaviors (Buyse et al., 2008; Hamre \& Pianta, 2005; Merritt et al., 2012). From the point of view of a child's development, identity-construction and well-being, studying the quality of 
the teacher-child relationship in cases where children have difficulties in self-regulation is of especial importance. Also, in order to attain a deeper understanding of this relationship we need to understand the child's position in this respect.

\section{The position of the child in relational context}

Position (Bamberg, 2004) is a concept which expresses interactional agency, practices and the thoughts behind interactional situations, for example teachers' concepts about of a child (Lundan, 2009, 21). Actor positions can be identified in interactional situations. They can be stable or they can change over time, and they are influenced by power structures (Lundan, 2009). In daycare centers, teacher-child relationships are built on everyday interaction, which can easily be rendered negative by teachers when working with children who have socio-emotional and behavioral problems (Pihlaja, 2008). The challenges presented by problematic teacher-child interaction appear, in particular, in the way the participants are positioned (Lundan, 2009; Suoninen \& Lundan, 2005). Negative positioning promotes negative identity construction (Lundan, 2009); for example, a narrative 'bad guy' identity may be strengthened in the interactional process (Suoninen \& Lundan, 2005). In contrast, in positive teacher-child interaction, a child's positive narrative identities are strengthened, and hence in interaction situations teachers offer the child a variety of positive positions (Lundan, 2009). Studying parents' narratives on the teacher-child relationship can offer a new perspective on how children with difficulties in self-regulation are positioned in the ECEC context.

\section{Aim and research questions}

This study focused on the relationship between teachers and children with difficulties in selfregulation in the Finnish ECEC context. The teacher-child relationship and the position of a child were studied from the parents' point of view. The following research questions were set:

1. What kinds of teacher-child relationships can be identified in the narratives of the parents?

2. How are the children positioned in the different kinds of teacher-child relationships narrated by their parents?

\section{Method}

\section{Context of the study}


This study was conducted in the Finnish ECEC setting. According to the current Finnish ECEC legislation, all children have a subjective right to public ECEC services before the child starts compulsory formal education, which begins in the year the child reaches the age of 7 . Further, the 6 -year-old children attend free, mandatory pre-primary education for one year, 4 hours a day. The aim of the pre-primary education is to provide all children with an equal opportunity of learning the basic skills needed for primary school. ECEC services are administrated by Ministry of Education and Culture. Municipalities have the main responsibility for arranging ECEC services in Finland. In the National Curriculum Guidelines on ECEC in Finland (2005), the guiding principle for education is the holistic view that care, education and teaching form an integrated whole. ECEC is carried out as teamwork by well-educated and multi-professional educators. Typically three educators work together in groups of 3- to-6-year-old children In Finland. In this study, all educators in the group, weather kindergarten teachers or practical nurses (day care nurses), are referred to as teachers.

\section{Participants and data collection}

The data for this study consist of interviews conducted by the first author with 21 parents (17 mothers and 4 fathers) over the period 2009-2013. These parents all reported that their child had difficulties in controlling his/her behavior and emotions and was thus prone to behaving in ways that could be interpreted as challenging. Typically, these problems had also been noticed by the teachers. Most of the parents had sought external help for themselves and their children from the Finnish 'Family School’ program, which was organized by the family counselling center for families where a child had difficulties in self-regulation. This was the source for recruiting most of the participating parents. Some parents were also reached by sending the research request to different daycare centers, primary schools, and to the parents of the local ADHD association. Most of the interviewed parents had been clients of daycare services for several years, or at the least for 10 months. Participation in the study was voluntary. Parents were informed about the study and its ethical guidelines (e.g. confidentiality and sensitivity). At the beginning of the interviews, the interviewer gave an honest description of the aim of the study and how the analysis and reporting of the data would be implemented in such a way that it would not be possible to identify the participants, concerning the children and the daycare-centers narrated by the parents. Parents were also told that the original data would only be used by the researcher (first author). The parents were then asked to give their informed consent and they were also informed to have the possibility to withdraw from the study at the any point during the research process. 
In a narrative research framework (Riessman, 2008), qualitative semi-structured interviews were conducted in dialogical interaction with the participants. Parents were asked to talk on the following main themes: i) their child in the daycare center, ii) their child's relations with the teachers and other children, and iii) good and unhappy experiences of the educational partnership. The interviews can be described as conversational and dialogical storytelling situations (Fraser, 2004; Riessman, 2008). Parents were encouraged to speak about their own experiences, thoughts and emotions openly and freely. If needed, they were asked more specific questions related to these themes, such as 'Could you tell me what a typical day would be like for your child in the daycare center' or 'Could you tell me what typically happens when you pick your child up from the day care center'. The interviews lasted an average of 1 hour 15 minutes. The shortest interview lasted about one hour and the longest about 3 hours.

\section{Data analysis}

All the interviews were audio-recorded and afterwards transcribed verbatim by the first author and literally as a written protocol. The data were analyzed mainly by applying a narrative approach (Riessman, 2008; Spector-Mersel, 2010). The analytical process comprised three phases. In the first phase, all the interviews were carefully read and all parental narratives concerning the teacher-child relationship were selected. These narratives pertained to i) interaction between a teacher and the child, ii) teachers' concepts, attitudes and expectations with respect to the child and the child's activity, iii) what teachers had told the parents about their child iv) what the child had told his or her parents about the teacher-child relationship, and v) the parents' interpretation of the teacher-child relationship. In total, 215 teacher-child relationship narratives were selected for the analysis.

In the second phase, after the selection of the narratives, they were categorized in accordance with their content and tone initially into the categories of negative, neutral and positive teacher-child relationship following the principles of narrative analysis (Polkinghorne, 1995) and categoricalcontent reading (Lieblich, Tuval-Mashiach \& Zilber, 1998). Most of the interviews typically included narratives from all three categories. After re-reading the narratives, the categories were renamed according to their content, and the number of occurrences were counted, as follows: negative narratives were labelled 'problematic' $(n=62)$, neutral narratives were labelled 'neutral' $(n=103)$, and positive narratives 'caring' $(\mathrm{n}=50)$ teacher-child relationship narratives. After identifying and re-naming the three different kinds of relationship narratives, the narrative that was considered to best represent the characteristics of its category was selected and an abstract of it was created as an illustrative example. 
In the third phase of the analysis, the positioning of the child was examined in 215 teacher-child relationship narratives. Applying Bamberg's (2004) notions of narrative positioning, we initially identified and named 12 different ways in which the child was positioned in relation to the teacher. Some of them were later combined, leaving 9 positions, which were named and their frequency counted. Three positions in each category were recognized.

\section{Findings}

In this section, we present the findings related to the different kinds of teacher-child relationships and the positioning in these relationships of a child with difficulties in self-regulation as narrated by the child's parents. In order to guarantee the anonymity of the participants, we do not report the names of the parents, children, daycare centers or teachers, but, where needed, use pseudonyms.

\section{Teacher-child relationships narrated by the parents}

As can be seen in Table 1, the teacher - child relationship was most frequently described as neutral ( $n=103)$, followed by problematic $(n=62)$ and caring $(n=50)$. Since the relationship was more frequently described as neutral and caring $(n=153)$ than as problematic $(n=62)$, we would interpret the parents' narratives of the teacher-child relationship as mainly positive. Next, we describe each category of teacher-child relationship and present a typical story to illustrate each relationship

Table 1: Teacher-child relationship narratives identified in the parents' interviews

\begin{tabular}{|c|c|c|c|}
\hline $\begin{array}{l}\text { Narrated teacher-child } \\
\text { relationship } \mathrm{n}=215\end{array}$ & $\begin{array}{l}\text { Neutral relationship } \\
\text { narratives } \\
n=103\end{array}$ & $\begin{array}{l}\text { Problematic } \\
\text { relationship narratives } \\
n=62\end{array}$ & $\begin{array}{l}\text { Caring relationship } \\
\text { narratives } \\
n=50\end{array}$ \\
\hline Quality & $\begin{array}{l}\text { Formal, confidential, } \\
\text { professional }\end{array}$ & $\begin{array}{l}\text { Conflictual, distant, } \\
\text { unprofessional }\end{array}$ & $\begin{array}{l}\text { Warm, intimate, } \\
\text { reciprocal }\end{array}$ \\
\hline Typical content & $\begin{array}{l}\text {-Teacher gets along with } \\
\text { the child and vice versa } \\
\text {-Teacher can cooperate } \\
\text { with the child } \\
\text { - Teacher's report of the } \\
\text { day is neutral }\end{array}$ & $\begin{array}{l}\text {-Teacher and/or child do } \\
\text { not like each other } \\
\text { - Teacher finds it } \\
\text { difficult to cooperate } \\
\text { with the child } \\
\text {-Teacher's negative } \\
\text { information of the child } \\
\text { and child's behavior }\end{array}$ & $\begin{array}{l}\text {-Teacher and child like } \\
\text { each other very much } \\
\text {-Teacher knows how to } \\
\text { cooperate with the child } \\
\text {-Teacher's talk about the } \\
\text { child's personality, } \\
\text { individual needs and } \\
\text { well-being }\end{array}$ \\
\hline
\end{tabular}


The neutral teacher-child relationship reflects the parents' description of the relationship as formal, confidential and professional. According to the parents, the child and the teacher got along with each other and the teacher cooperated well with the child. Although at home the child did not talk about teachers very much and the child was not specially attached to any particular teacher, the relationship was nevertheless described as good and well-functioning by the parents. The teachers were narrated as reacting professionally and in an emotionally neutral way to the challenging behavior on the part of the child. The parents were also informed in a neutral way about the challenges posed by the child and the events of the day when the parents came to pick their child up. The parents trusted the teachers to manage challenging situations and to give the child the pedagogical support needed in the group. The narrative by Paul's father illustrates the typical characteristics of the neutral teacher-child relationship.

Paul needed special attention, arrangements and special activities more than the other children in the group because of his challenging behavior. The teachers really made an effort to see that Paul got all the special support and individual guidance he needed. The teachers noticed his particular challenges and deal with them neutrally. They devised suitable supportive activities. They also tried to obtain further knowledge about his challenges. The teachers really have been professionals right from the very beginning.

\section{Problematic relationship}

The problematic teacher-child relationship was described as conflictual, difficult, distant and unprofessional by the parents. According to the parents, one or some of the teachers did not get along with the child or 'they just didn't like each other', as one mother put it. The parents had further noticed that the child's behavior was a cause of trouble and confusion to the certain teachers and it was difficult for these teachers to understand the child's behavior and to manage challenging situations with the child. The parents thought that a situation where a teacher lacked experience and knowledge about children with challenging behavior could have a negative influence on the teacher-child relationship. The teachers themselves had also said that they needed professional help in order to support the child. The problematic teacher-child relationship was also described as lacking in warmth on the teacher's part. As an example of, we next present the narrative by Mark's mother, which exemplifies this kind of relationship:

Mark caused trouble from the very beginning after starting in a daycare-center. It was only the third day, when the daycare nurse stood, hands on hips, and asked: "What can we do with such a child like this?” Another nurse said that Mark will be assigned to a 
special group when he starts primary school. Mark’s liveliness and impulsive behavior complicated his teacher and peer relationships and caused the teachers extra trouble and stress. After one conflict I asked the teacher whether she could take a positive attitude towards our son, and she answered: “If I answer to your question, I will be unprofessional.” I felt that the teacher viewed Mark as just too wild or too difficult. The situation got so bad that they said they would put Mark in another group.

\section{Caring relationship}

The caring teacher-child relationship was characterized as reciprocal, warm, intimate and affectionate, with strong emotional connectedness between both parties. The parents narrated that a lot of the teachers had formed a special relationship with the child. The teachers were 'strongly attached to the child' and vice versa, and the child brought much joy to the teachers, who 'really cared for these children'. According to one mother, for her child one teacher in particular was 'the most loved'. The children spoke a lot about their teachers at home. The teacher and the child interacted closely with each other and shared a nice sense of humor, as one mother reported. According to the parents, the teachers also described the day's events to the parents in a warm and humorous way. The teachers acted professionally and were committed to their pedagogical work. The parents emphasized the professional knowledge the teachers had about the children, their individual needs and how to support their individual well-being in the daycare center. These teachers noticed and accepted the child's unique personality. Matthew's mother narrated the teacher-child relationship in the following way:

Matthew had a very special relationship with one particular teacher. The teacher liked him so much. Our son is in her (teacher's) heart. The teacher understood Matthew and knew how to work with him in everyday challenging situations and conflicts. The child's temperament was the starting point when cooperating with the child. The child's impulsive behavior was not a problem for the teacher and she did not fixate on the child's challenging behavior. The teacher knew who the child was, she accepted him and trusted the child. Once the teacher told me how: "Matt is so lively and wild and one’s always a bit apprehensive about what might happen next, but he is so sweet and lovely too.”

\section{Positioning of the challengingly behaving children as narrated by their parents}

Next, we illustrate how the child was positioned in the neutral, problematic and caring teacher-child relationship narratives of the parents. Table 2 describes these positions. 
Table 2: Positioning of the child in the parents' narratives of the teacher-child relationship

\begin{tabular}{|c|c|c|c|}
\hline $\begin{array}{l}\text { Narrated } \\
\text { relationship }\end{array}$ & $\begin{array}{l}\text { Neutral relationship } \\
\text { (103 narratives) }\end{array}$ & $\begin{array}{l}\text { Problematic relationship } \\
\text { (62 narratives) }\end{array}$ & $\begin{array}{l}\text { Caring relationship } \\
\text { (50 narratives) }\end{array}$ \\
\hline $\begin{array}{l}\text { Positioning } \\
\text { of the child }\end{array}$ & $\begin{array}{l}\text { Unconventional child (20) } \\
\text { - different kind of child } \\
\text { - challenges presented by the } \\
\text { child are noticed and } \\
\text { accepted } \\
\text { Child in need of special } \\
\text { support (44) } \\
\text {-teachers make an effort to } \\
\text { support the child as part of } \\
\text { their work } \\
\text { Ordinary child (39) } \\
\text { - child is like the others } \\
\text { - child's challenging behavior } \\
\text { was not noticed }\end{array}$ & $\begin{array}{l}\text { Wrong kind of child (25) } \\
\text { - child is doing the wrong } \\
\text { things } \\
\text { - negative features of the } \\
\text { child are emphasized } \\
\text { Special child (13) } \\
\text { - teachers would like a } \\
\text { specialist to support the child } \\
\text { or to provide a diagnosis for } \\
\text { the child } \\
\text { Troublesome child (24) } \\
\text { - child causes trouble and } \\
\text { conflicts intentionally } \\
\text { - child is disobedient } \\
\text { - child is to blame and is } \\
\text { stigmatized }\end{array}$ & $\begin{array}{l}\text { Good child (21) } \\
\text { - talented child in some } \\
\text { contexts } \\
\text { - positive features of the } \\
\text { child are emphasized } \\
\text { Individual child (18) } \\
\text { - child is an unique } \\
\text { personality, whose welfare } \\
\text { and individual needs are } \\
\text { important in daycare } \\
\text { Unique child (11) } \\
\text {-very special, and important } \\
\text { to the teacher } \\
\text { - child and child's } \\
\text { personality as source of } \\
\text { delight }\end{array}$ \\
\hline
\end{tabular}

Positioning of the child in the neutral teacher-child relationship

In the case of the neutral teacher-child relationship, we identified three ways of positioning of the child: as an unconventional child, a child who needs special support, and as an ordinary child. An unconventional child was described as a different kind of child, who was challenged in controlling his/her emotions and behavior in certain situations. This was accepted by the teachers as a neutral and normal fact. According to the parents, the teachers emphasized that the behavior of the child was not intentional but it is due to difficulties in self-regulation. Child was also positioned as a child who needs special support. The child's special needs were noticed and the teachers supported the child as a part of their normal educational work. The child was also positioned as an ordinary child in the neutral teacher-child relationship narratives. One mother described how the teachers took a similar attitude to the child as to any other child and, if something troublesome happened, the teachers were quick to emphasize that such things can happen to any child. The teachers did their best to avoid the child being stigmatized as a troublesome child.

Some parents also narrated that the teachers did not tell them about troublesome situations that must have occurred during the day. If so, this kind of omission can be interpreted as a desire by the teachers to represent the child to the parents as just another ordinary child. According to some 
parents, the image of their child that teachers conveyed to them was overly positive. The child's problems were spoken of as not so significant or they were not noticed by the teachers. This, according to one father, was the reason why the child was unable to get help and professional support early enough. One mother was very sorry that her child's difficulties were attributed to the child's liveliness and not a sign of severe difficulties, as was diagnosed later on. Another mother wondered whether the teachers did not want to tell them about all the difficulties they had encountered in the daycare center, or was it just that the child only behaved challengingly at home. The mother felt that she had not been heard by the teachers. She was also worried that her child might be acting in too normal and too agreeable a way in the daycare center. She was concerned whether their son could really be the boy that he appeared to be in the daycare center and whether the teachers understood him and his personality as the boy they knew at home. Despite the dissatisfaction of these parents with the way the teachers spoke about the child's behavior they nevertheless described the teacher-child relationship in a positive way as functional and neutral.

\section{Positioning of the child in the problematic teacher-child relationship}

In problematic teacher-child relationship narratives three ways of positioning of the child were identified: as a wrong kind of child, a special child and as a troublesome child. Such a wrong kind of child was narrated as behaving badly and doing things that were wrong most of the time in the daycare center. The negative features of the child were emphasized by the daycare staff, which was why it was difficult for the parents to meet the teachers when picking their child up. One mother wondered why only negative features were documented, as there were positive things in the child too. A child was compared by the teachers to the other children of the same age. The child was unlike the other children, and just did not fit into the mold of a normal child, as one mother expressed it. Some parents stated that the child was too wild, too bad or too difficult because he/she was not good at the skills the teachers expected them to have, such as listening, concentrating, and behaving peacefully. For example, one teacher had wondered how: 'the child is able to play well, but only with the girls and not with the other boys, as he should be doing.'

The child was also positioned as a special child in the parents' narratives, which for them was a problematic and negative thing. In some narratives, the teachers had proposed that a specialist be asked to observe the child or to provide a diagnosis for the child, which some parents found scary and threatening because of the way this information was presented to them. The parents and the teachers did not find a common understanding of the severity of child's problems. One mother described a communication with a teacher after her son had caused a harmful situation in the 
daycare center: 'After some kind of pinching and disturbance the teacher suggested their need to investigate the reason for the problematic behavior.' The mother did not see the difficulties as bad as the teachers did.

A troublesome child was narrated to be a nasty and difficult child, who intentionally caused trouble. The child hit others, caused conflicts, was disobedient and acted in ways that a child was not supposed to act, behaviors which made the parents think about how bad, nasty and difficult the child is. The child, as one who teased others, was also positioned as stigmatized and always the quilty party. When conflicts arose between the children, the child was blamed, as Peter's mother narrates: 'When something happened, it was Peter who was blamed...and he learned to apologize even when he hadn't done anything wrong and once he was accused of bullying, and he wasn't even in the daycare center on that day.' Peter himself had also asked his mother at home, why he is always being blamed. Some parents were afraid that the stigma would follow the child from one group of children to another via documentation, individual ECEC plans or internal communication within the daycare staff.

\section{Positioning of the child in the caring teacher-child relationship}

The child was positioned as a good, unique and individual child in the parents' narratives of the caring teacher-child relationship. The child was typically described as a good child who was talented, especially in certain areas. Despite the many difficulties the child had in self-regulation in specific situations, the child's positive features and strengths were emphasized by the teachers in their communication with the parents. When talking about the child's challenging behavior, the teachers emphasized the context of that behavior. The child was described by the teachers as a whole personality. Parents narrated the teachers as knowing the child as he/she is and accepting the child unconditionally: according to one mother: 'They saw the child in a realistic way, they noticed the challenges the child presented, and what is difficult for a child, but they also noticed and saw the strengths of the child, giving no special weight to either aspect.' Despite the challenging behavior of the child, the teachers saw the child as skillful, talented, good and unique. The teachers strengthened the parents' faith that the child is inherently good and that the parents can cope with the child, even in the face of severely challenging behaviors. The teachers had a major role in supporting the parents' belief in themselves and in trusting the child. They also had a major role in mediating a positive image of the child. This was particularly emphasized in the individual ECEC planning discussions, as described by Mathew's mother: 'In that discussion I realized that there 
really are so many beautiful and good things in our child, and that these features are visible in the daycare center.'

The child was also narrated by the parents in the relational context as a unique child. A child was described as a cause of special joy to some teachers, according to whom the child was lovely and irresistible. For some teachers, the child was special. One teacher told a mother how: 'Miika is always such a happy boy, and enthusiastic about doing things, and how he never complains, these are his very strengths.' These teachers knew how to cooperate with the child in challenging situations. One mother narrated how the teacher had a clear image of the child and child's special needs and how to cooperate with the child. The teacher had understood that: 'Commanding the child just doesn't work', and according to the mother, understanding this was the key element in achieving positive cooperation with the child. In the parents' narratives, the teachers were positioned as specialists who understood the child and child's individual needs and who knew how to work with the child. The teachers were described as having rich knowledge about children and a strong belief in themselves as professionals, and supported the child's well-being and development. The child was positioned in these narratives as an 'individual child' with individual needs.

\section{Discussion}

In this qualitative study, we examined the teacher-child relationship in the Finnish ECEC context in cases where a child has difficulties in self-regulation. This relationship was explored from the parents' point of view, with the additional aim of enriching understanding of the ways the child was positioned in this relational context. It has been reported that challenging behavior by a child puts at risk the possibility of forming a good quality teacher-child relationship (e.g. Mantzicoupoulos, 2005). However, this present study revealed that in such cases the relationship between a teacher and a child is not always narrated as challenging and negative. Three different teacher-child relationships were identified in the parents' narratives: neutral, problematic and caring relationships. Thus the relationships described by the parents ranged widely from conflictual through formal to warm and intimate. Furthermore, we discovered that the way the children were positioned in these three different teacher-child relationship narratives also varied from negative through neutral to positive.

The caring teacher-child relationship described by the informants resembled the 'positive relationship', characterized by warmth, closeness and attachment, reported in previous studies (Pianta, 1999; Sabol \& Pianta, 2012). The caring relationship was also described as unique, and 
based on strong positive emotions on the part of the teacher. The neutral teacher-child relationship was narrated also as a positive relationship, but was more a functional and professional relationship based on neutral emotions on the part of the teacher. In both types, the teachers were narrated as positively involved with the children and their work, and able to meet the children's individual and special needs. The problematic teacher-child relationship described here resembled previous conceptualizations of teacher-child relationship as dysfunctional, conflictual, insecure, uninvolved, distant and angry (Pianta, 1994). Compared to previous findings, however, the parents in this study did not narrate the teacher-child relationship by drawing on such concepts of dependence, clinginess or over-reliance.

Previous studies have found that children who behave challengingly in a day care center are positioned negatively (e.g. Pihlaja, 2008). Impulsive children can sometimes become scapegoats and are blamed for all the aggressive actions that occur during peer conflicts (Singer \& de Haan, 2011). This study complements the current understanding by showing a broader spectrum in the ways children were positioned in ECEC settings. The nine positioning found varied from negative (such as troublesome) to neutral and positive (such as unconventional, ordinary and unique). In some narratives, the child's challenging behavior seemed to be problematic for teachers while in other narratives it was narrated as an acceptable fact of life. Overall, the study indicates that the relationships between teachers and challengingly behaving children in ECEC settings are multiple, and that a child can be variously positioned in this relational context.

\section{Conclusions and implications}

Via a narrative approach (Elliott, 2005), this study showed what kinds of meanings parents attribute to the teacher-child relationship. The parents reflected a lot on the emotional aspects of the teacherchild relationship. They narrated teacher-child closeness very positively; this may also derive from the cultural context (Gregoriadis \& Grammatikopoulos, 2014). They reflected on whether the teachers understood, accepted and liked the child or not. The parents were aware that their challengingly behaving child was not like the other 'ordinary' daycare children or what teachers' expect and would wish a child to be, such as socially competent and independent child with good self-regulation abilities (see Alasuutari \& Markström, 2011). Emotional support from the teachers was important for the parents, and as the latest research has shown it is also important in supporting the children with difficulties in self-regulation (Buyse et al., 2008; Merritt et al., 2012). The parents also commented on pedagogical aspects of the teacher-child relationship by reflecting on whether or not the teacher is able to interact in a pedagogically meaningful, warm and respectful way with the 
child, and able to cope with the child. The findings showed that teachers' professional involvement and way of working with a child, along with professional love (Page \& Elfer, 2013), were important for the parents when reflecting on the teacher-child relationship.

This paper emphasizes the relational aspects of the ECEC context and gives an insight into the teacher-child relationship from the parental point of view. The importance of the teacher-child relationship was emphasized in the parents' narratives. The nature of the relationship was connected to how a child was positioned, which in turn reflected teachers' concepts of the child (Lundan, 2009); these varied in this study from the 'good' child to the 'bad' child. The findings of this study have implications for teachers' pre-service and in-service training. For teachers, this study offers tools to reflect on and analyze the teacher-child relationship and how a child is positioned in this relationship, and to find novel positive ways of positioning a child in relational situations and of modifying their concepts of a child. The findings further indicate that teachers should pay attention to what kind of image of their child they convey to the parents in interactional situations, especially when a child's behavior is challenging.

The findings also show the importance of listening to parents in order to understand a child's behavior, personality, interests, and individual needs. All this lays a foundation for sensitive teacherchild interaction and for understanding and accepting the child unconditionally (see Buber, 1993; Lundan 2009). This study emphasizes the importance of a positive teacher-child relationship and highlights the role of the structural dimensions of ECEC services in ensuring good quality teacherchild relationships (Howes \& James 2002). More attention should also be given to the adult-child ratio, stability of teachers, teacher's education and the possibility for teachers to reflect on teacherchild relationship in the context of giving professional guidance.

Difficulties in self-regulation manifest in many ways, all of which influence the teacher-child relationship. Most of the parents described their child as a hyperactive child who was unable to concentrate and who had difficulties in social behavior, especially with other children. The unique child was in some narratives described as a mesmerizing personality, suggesting that it may not be so hard to like this kind of misbehaving, hyperactive and impulsive child. In this study, we aimed to capture a parental perspective on the teacher-child relationship. There were also some limitations in this study. We are aware that teacher and child narratives and observational data would also have been important in order to gain a more profound understanding of teacher-child relationship. Observation as a method has been widely used in studying the teacher-child relationship in schools. 
We suggest that greater use of it should be made when researching children with difficulties in selfregulation in the ECEC context. Discussions with children are also an important way of hearing their voices. When generalizing the present findings, we need to remember that most of the children in the sample were boys (only 4 girls). According to their parents, the children's difficulties in selfregulation were mainly manifested as externalizing behavior, which does not cover the full range of difficulties in self-regulation. Furthermore, the children's parents (mostly mothers) can be regarded as active parents, who were willing to seek help and to participate in the study. In sum, the findings of this study enrich understanding of the variety in the teacher-child relationship. Finally, we suggest that all teachers should try to form at least a neutral teacher-child relationship with all the children in the ECEC and school contexts. The starting point for moving in a more positive direction away from a problematic teacher-child relationship is teachers' awareness of their concept of the child underlying that relationship.

Notes on contributors

Erja Rautamies, MA (Psych.) is a PhD Candidate, in early childhood education. Rautamies works as a University teacher in the Department of Education at the University of Jyväskylä. Her teaching responsibilities of bachelor level are focused on development and wellbeing of children. Her research interests include educational partnership and children with difficulties in self-regulation. This article is a part of her doctoral thesis.

Pirjo-Liisa Poikonen, PhD., is a University Researcher (emerita) in the Department of Education at the University of Jyväskylä. Her research interests include curriculum development. In addition her current studies focus on issues of parents and teachers collaboration, social interaction, and partnership in pre-primary and school contexts and factors contributing children's transition from pre-primary context to school context. She has been researcher in the First Steps study and Children's socio-emotional wellbeing and daily family life in a 24-h economy, both of the studies include cultural comparison.

Katja Vähäsantanen, Ph.D., is a Post-doctoral researcher in the Department of Education at the University of Jyväskylä. Her current research interests include professional identity, agency, leadership, learning, and emotions in work organizations. 
Marja-Leena Laakso, Ph.D., is a Professor of Early Childhood Education, and a Dean of the Faculty of Education at the University of Jyväskylä. Her research interests include risk and protective factors in child development, children's and families wellbeing in 24-h economy, children's over activity and challenging behavior, adults supporting children's emotion regulation, children's prelinguistic and early language development

\section{References:}

Alasuutari, M. \& Markström, A.-M. (2011). The making of the ordinary child in preschool. Scandinavian Journal of Educational Research, 55(5), 517-535.

Bamberg, M. (2004). Positioning with Davie Hogan. Stories, tellings and identities. In C. Daiute \& C. Lightfoot (Eds.) Narrative analysis: Studying the development of individuals in society (pp. 135159). Thousand Oaks, CA: Sage.

Barkley, R. A. (2004). Attention-deficit/hyperactivity disorder and self-regulation. Taking an evolutionary perspective on executive functioning. In R. F. Baumeister \& K. D. Vohs. (Eds.) Handbook of self-regulation. Research, theory and applications (pp. 301-323). New York: Guilford Press.

Bergin, C. A., \& Bergin, D. A. (2009). Attachment in the classroom. Educational Psychology Review, 21(2), 141-170.

Bretherton, I. (1991). The roots and growing points of attachment theory. In C. M. Parkes; J. S. Hinde \& P. Marris (Eds.) Attachment across life cycle (pp. 9-32). London; New York: Routledge.

Bretherton, I. (1985). Attachment Theory: Retrospect and Prospect. Growing points of attachment theory and research. Monographs of the Society for Research in Child Development, 50, 3-35.

Bromer, J., Paulsell, D., Porter, T., Henly, J. R., Ramsburg, D., Weber, R. B. 2011. Family-sensitive caregiving. A key component of quality in early care education arrangements. In M. Zaslow, I. Martinez-Beck, K. Tout \& T. Halle (Eds.). Quality measurement in early childhood settings (pp. 161-190). Baltimore, Md. : Paul H. Brookes Pub. 
Bronson, M. B. (2000). Self-regulation in early childhood. Nature and nurture. New York: Guilford Press.

Buber, M. (1993). Minä ja sinä (suomennos J. Pietilä). [Ich und du]. Porvoo: WSOY.

Buyse, E., Verschueren, K., Doumen S., Damme, J. V. \& Maes, F. (2008). Classroom problem behaviour and teacher-child relationships in kindergarten: The moderating role of classroom climate. Journal of School Psychology, 46(4), 367-391.

Doumen, S, Verschueren, K. Buyse, E. Germeijs, V. \& Soenens, B. (2008). Reciprocal relations between teacher-child conflict and aggressive behaviour in kindergarten: A three-wave longitudinal study. Journal of Clinical Child and Adolescent Psychology, 37(3), 588-599.

Ebbeck, M. \& Yim, H. Y. B. (2009). Rethinking attachment: fostering positive relationships between infants, toddlers and their primary caregivers. Early Child Development and Care, 179(7), 899-909.

Elliott, J. (2005). Using narrative in social research: qualitative and quantitative approaches. Thousand Oaks, CA: Sage.

Fattore, T., Mason, J. \& Watson, E. (2006). Children's conceptualization(s) of their well-being. Social Indicators Research, 80(1), 5-29.

Fraser, H. (2004). Doing narrative research. Analysing personal stories line by line. Qualitative Social Work 3(2), 179-201.

Fumoto, H. (2011). Teacher-child relationship and early childhood practice. Early Years, 31(1), 1930.

Gregoriadis, A. \& Grammatikopoulos, V. (2014). Teacher-child relationship quality in early childhood education: the importance of relationship patterns. Early Child Development and Care, 184(3), 386-402. 
Hamre, B. K. \& Pianta, R. C. (2005). Can instructional and emotional support in the first grade classroom make a difference for children at risk of school failure? Child Development, 76(5), 949967.

Howes, C. \& James, J. (2002). Children's social development within the socialization context of children and early childhood education (pp. 137-155). In P. K.Smith \& C. H. Hart (Eds.) The Blackwell handbook of childhood social development. Oxford: Blackwell.

Joshi, A. (2009). What do teacher-child interactions in early childhood classrooms in India look like? Teacher's and parent’s perspective. Early Child Development and Care, 179(3), 285-301.

Kikas, E., Poikonen, P.-L., Kontoniemi, M., Lyyra, A.-L., Lerkkanen, M.-K. \& Niilo, A. (2011). Mutual trust between kindergarten teachers and mothers and its associations with family characteristics in Estonia and Finland. Scandinavian Journal of Educational Research, 55(1), 2337.

Lieblich A., Tuval-Mashiach R. \& Zilber, T. (1998). Narrative research: reading, analysis and interpretation. London: SAGE.

Lundan, A. (2009). Kutsu dialogisuuteen. Diskurssianalyyttinen tapaustutkimus kasvattajan ja lapsen haasteellisesta vuorovaikutuksesta päiväkodissa. [Invitation to dialogue. A discourse analytic case study of challenging interplay situations between teacher and child in daycare center]. Acta Universitatis Tamperensis 1463. Tampere: Tampere University Press.

Manzicopoulos, P. (2005). Conflictual relationships between kindergarten children and their teachers: Associations with child and classroom context variables. Journal of School Psychology, 43(5), 425-442.

Merritt, E. G., Wanless, S. B., Rimm-Kaufman, S. E., Cameron, C. \& Peugh, J. L. 2012 The contribution of teachers' emotional support to children's social behaviours and self-regulatory skills in first grade. School Psychology Review. 41(2), 141-159. 
Mishra, A. K. (1996). Organizational responses to crisis: the centrality of trust. In R. M. Kramer \& T. R. Tyler (Eds.), Trust in organizations: Frontiers of Theory and Research (pp.261-288). London: SAGE.

National Curriculum Guidelines on Early Childhood Education and Care in Finland, 56/2005. Helsinki: Stakes. Retriewed from https://www.julkari.fi/bitstream/handle/10024/75535/267671cb0ec0-4039-b97b-7ac6ce6b9c10.pdf?sequence=1

O’Connor, E. (2010). Teacher-child relationships as dynamic systems. Journal of School Psychology, 48(3), 187-218.

O’Connor, E., Dearing, E. \& Collins, A. B. (2011). Teacher-child relationship and behavior problem trajectories in elementary school. American Educational Research Journal, 48(1), 120-162.

Page, J. \& Elfer , P. (2013). The emotional complexity of attchment inteactions in nursery. European Early Childhood Education Research Journal, 21(4), 553-567.

Pianta, R. C. (1994). Patterns of relationship between children and kindergarten teachers. Journal of School Psychology, 32(1), 15-31.

Pianta, R. C. (1999). Enhancing relationships between children and teachers. Washington, DC: American Psychological Association.

Pianta, R. C. \& Stuhlman, M. (2004). Teacher-child relationships and children's success in the first years of school. School Psychology Review, 33(3), 444-458.

Pihlaja, P. (2008). 'Behave yourself!' Examining meanings assigned to children with socioemotional difficulties. Disability \& Society 23(1), 5-15.

Polkinghorne, D. E. (1995). Narrative configuration in qualitative analysis. In A. J. Hatch \& R. Wisniewski (Eds.) Life history and narrative (pp. 5-23). London: Falmer Press.

Riessman, C. K. (2008). Narrative methods for the human sciences. Thousand Oaks: Sage Publications. 
Riikola, T; Moilanen, I., Puustjärvi, A., Laukkala, T., Närhi, V., Olsen, P., Pihlajakoski , L., Raevuori, A., Virkkunen, L. \& Voutilainen, A.2013. Käypä hoito suositukset: ADHD (aktiivisuuden ja tarkkaavuuden häiriöt, lapset ja nuoret). [The updated Current Care Guideline for children and adolescents with ADHD ]. Duodecim. Retrieved from 1.8.2015 from http://www.terveyskirjasto.fi/terveyskirjasto/tk.koti?p_artikkeli=khp00071.

Rothbart, M. K. \& Derryberry, D. (2002). Temperament in children. In C. Hofsten \& L. Bäckman (Eds.), Psychology at the turn of the millennium: congress proceedings. Vol. 2, Social, developmental, and clinical perspectives (pp.17-35). Hove: Psychology Press.

Sabol, T. J. \& Pianta, R. C. (2012). Recent trends in research on teacher-child relationships. Attachment \& Human Development, 14(3), 212-231.

Savina, E. (2014). Does play promote self-regulation in children? Early Child Development and Care 184(11), 1692-1705.

Singer, E \& de Haan, D. (2011). Fostering a sense of belonging in multicultural childcare settings. In M. Kernan \& E. Singer (Eds.). Peer relationships in Early Childhood education and care (pp. 88101). New York: Routledge.

Silver, R. B., Measelle, J. R. Armstrong, J. M. \& Essex, M. J. (2005). Trajectories of classroom externalizing behavior. Contributions of child characteristics, family characteristics, and the teacher-child relationship during the school transition. Journal of School Psychology, 43(1), 39-60.

Spector-Mersel, G. (2010). Narrative research. Time for paradigm. Narrative Inquiry 20(1), 204224.

Suoninen, E. \& Lundan, A. (2005). Encountering an uneasy child. In Narrative, memory \& everyday life. University of Huddersfield, Huddersfield, (pp. 223-229). Retrieved from http://eprints.hud.ac.uk/4957/2/Chapter_23_-_Eero_Suoninen_and_Arja_Lundan.pdf 
Tschannen-Moran, M. (2001). Collaboration and the need for trust. Journal of Educational Administration, 39(4), 308-331.

Vygotsky, L. (1962). Thought and language. Cambridge, MA: MIT Press.

Vygotsky, L. (1978). Mind in society: the development of higher psychological processes.

Cambridge, MA: Harvard University Press.

Zhang, X \& Nurmi, J.-E. (2012). Teacher-child relationships and social competence: A two-year longitudinal study of Chinese pre-schoolers. Journal of Applied Developmental Psychology, 33(3), 125-135. 